\title{
ECONOMIC
}

\section{The Emerging Service Economy}

\author{
by Patricia E. Beeson and
}

Michael F. Bryan

"I wish you wouldn't squeeze so," said the Dormouse, who was sitting next to her. "I can hardly breathe."

"I can't help it," said Alice very meekly,

"I'm growing."

"You've no right to grow here," said the

\section{Dormouse.}

"Don't talk nonsense," said Alice more boldly, "you know you're growing too."

"Yes, but I grow at a reasonable pace," said the Dormouse, "not in that ridicu. lous fashion."

-Alice's Adventures in Wonderland

Alice and the Dormouse in Lewis Carroll's classic story offer a lesson about human nature that can be applied to our economy.

Change often produces uncertainty and anxiety. When the economic environment changes, our anxieties are frequently reflected in political and legislative action.

So it is with the emerging service economy. Over a long period of time, the U.S. economy has become increasingly oriented towards the production and employment of services, while moving away from more traditional goods-producing industries. As the transition continues, legislative policies designed to protect goods producers have become more popular.

This Economic Commentary examines the expanding service economy and suggests that its emergence is not something to be feared. Rather, service sector growth reflects a natural-and inevitable-response to rising wealth.

Patricia E. Beeson, a visiling economist at the Federal Reserve Bank of Cleveland, is on leave from the University of Pillsburgh, where she is assistant professor, deparlment of economics. Michael F. Bryan is an economist al the Federal Reserve Bank of Cleveland. The authors would like to thank Katherine Barnum for her research assislance.

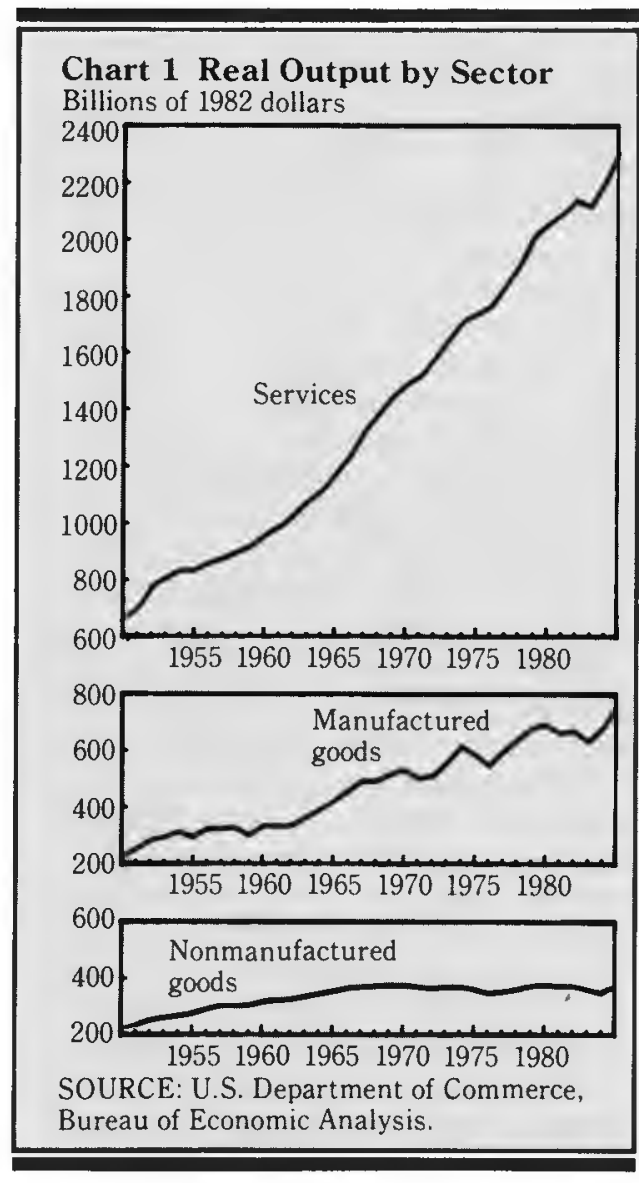

I Wish You Wouldn't Squeeze So Since 1945, our economy has undergone some dramatic changes; total employ. ment has nearly doubled and real output has increased almost threefold. While there have been increases in both output and employment in all three major sectors of the economy (manufacturing, nonmanufacturing goods, and services), the largest gains occurred in the service sector (charts 1-2).

The views stated herein are those of the authors and not necessarily those of the Federal Reserve Bank of Cleveland or of the Board of Governors of the Federal Reserve System.

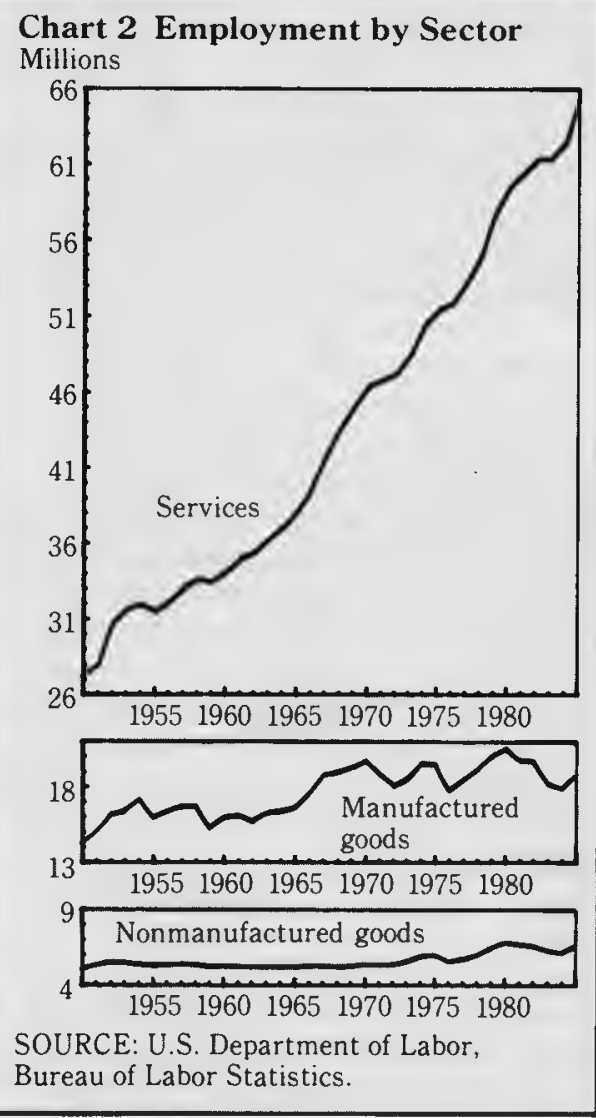

In 1950, total employment in the U.S. was 48.5 million workers. By 1984 , it had almost doubled to 91.1 million. Virtually all of the increase ( 90 percent) was in the service-producing industries. The majority of the remaining employment gains occurred in manu. facturing, with only slight gains in nonmanufactured goods employment (agriculture, mining, and construction). 


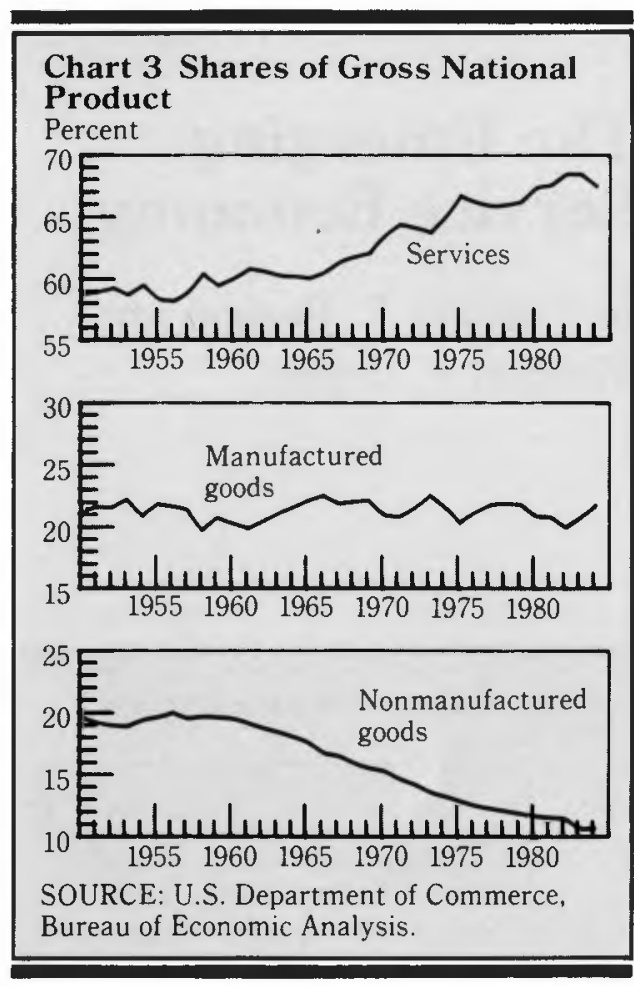

Similarly, almost 70 percent of our increased production since 1950 has occurred in service industries. The goods-producing sector, far from stagnant, however, nearly doubled its out put, primarily in U.S. manufacturing.

As a result of this growth, our economy has been transforming-from one where two of every five workers were employed in the goods-producing sector, to one where only about one of every four workers are presently employed by goods-producing industries. The composition of U.S. production has also changed, though less dramatically (chart 3). The share of total output produced in the service sector has increased from 58 percent in 1950 to 66 percent in 1984. Most of these gains have been at the expense of the nonmanufactured goods sector, with little or no change in the share of total output produced in the manufacturing industries.

The service economy has been growing, but output and employment growth has not been even for all service industries (see table 1). Indeed, real output growth has been greatest in the communications field. Other service industries showing above-average real output growth rates include utilities, wholesale trade, and other services (primarily health care and business services). Employment growth in services has been paced by the health care and business service fields, and has been above average for the finance, insurance, and real estate industries.

\section{Can't Help It, I'm Growing}

We can identify a number of likely sources of service-sector growth: the growth in the demand for services in the production of goods, increases in U.S. wealth, relative price adjustments between goods and service industries, and changes in labor force demographics.

Many service industries produce socalled intermediate services. These are services used for the production of goods, such as computer, engineering, legal, accounting, and advertising services. Over time, the value of intermediate services as a percent of the value of goods has been increasing, rising from 29 percent in 1947 to 37 percent in $1977 .^{2}$ In much the same way, the relative growth of the manufacturing sector during the industrial revolution was partially the result of shifting the provision of farming inputs from farmers to manufacturers. ${ }^{3}$

When the market for specialized business services was small, these services were either provided in-house by firms, or they were not produced at all. Growth of the U.S. economy expanded the business and professional services market and encouraged the development of firms specializing in these activities.

For example, at one time the majority of accounting services were provided in-house by firms in the goodsproducing sector. As the demand for these services grew, specialized accounting firms developed. Over time, goods-producing firms purchased more of their accounting services from independent accounting firms that are included in the service sector. Even had there been no increase in the demand for accounting services, the specialization of accounting firms would have been reflected as a measured increase in service sector activity.
Changes in the types of goods the economy produces have also increased the demand for intermediate services. Increased incomes and expanding markets have resulted in more product differentiation that, in turn, has increased the importance of services in the design, production, advertising, and distribution of these goods. Because of the gains from specialization and economies of scale in the provision of these services, proportionately more of these services are being provided by special. ized firms in the service sector rather than being provided in-house by firms in the goods-producing sector.

While increases in the demand for intermediate services have contributed to the increased service-sector activity, exact figures concerning their contribution to the overall growth of the service sector are not available. Based on an examination of input-output tables of the U.S. for 1947-1977, however, we estimate that only about 15 to 20 percent of the overall growth of the service sector during this period can be attributed to an increase in intermediate services. While this represents a significant increase, other factors, namely changes in U.S. productivity, are probably more powerful explanations for the growth of the service sector.

As a nation's average productivity rises, it becomes wealthier in the sense that it can now enjoy more goods and services for the same amount of resources. Economists call this phenomenon the income effect. Increased productivity changes consumption patterns and, hence, output.

The effect of rising productivity on the behavior of a nation is not unlike the effect of an income increase on the behavior of individuals. Low-income nations, like low-income households, consume proportionately high levels of necessities, or so-called lower-order goods. As incomes increase, we consume more of all normal goods and services, but the rate of growth of luxury (or higher-order) goods consumption is greater than that of necessities. ${ }^{4}$ More
1. See Michael F. Bryan, "Is Manufacturing Disappearing?," Economic Commentary, Federal Reserve Bank of Cleveland, (July, 1985).
2. These figures reflect both the direct and indi. rect service-sector requirements of the goodsproducing sector and were calculated from the input-output tables of the U.S. economy. These tables are not available after 1977 .
3. Fuchs (1968) and others have noted that while there has been a shifting of function from the goods-producing sector to the service sector, there has also been some shifting of functions in the opposite direction. For example, the production of pharmaceuticals has been shifted from being primarily in the service sector (drugstores) to being primarily conducted in the manufacturing sector 
Table 1 Output and Employment Growth by Service Industry

Average Annual Percentage Change, 1950-1985

Industry

All services

Communications

Utilities

Other services

Wholesale trade

FIRE*

Retail Trade

Government

Transportation

*Finance, insurance and real estate.

SOURCE: U.S. Department of Labor, Bureau of Labor Statistics.
Output (1982 dollars)

3.7

$6.7(1)$

$5.5(2)$

$4.4(3)$

$4.3(4)$

$3.7(5)$

$3.0(6)$

$2.3(7)$

$1.7(8)$
Employment

2.5

$1.8(6)$

$1.4(7)$

$3.3(1)$

$2.1(4)$

$3.2(2)$

$2.3(3)$

$2.1(5)$

$0.4(8)$ simply, consumption of most goods and services increases in response to a productivity improvement, but there is also a shift in this consumption toward an increasing proportion of luxury goods and services.

The distribution of necessities and luxuries is probably not even between goods-producing and service-producing industries. For example, the goods produced in agriculture, construction, and mining can probably be categorized as those that satisfy basic, lower-order needs. Manufacturing industries, however, are typically thought to produce goods that satisfy a somewhat higher order of needs; consequently, we expect these industries to develop after the nonmanufactured goods industries. On balance, it would seem that service industries represent production that satisfies an even higher order of needs, and that a blossoming service sector is characteristic of a nation (or individual) which or who has experienced a prolonged improvement in wealth.

The impact of the income effect on the distribution of a nation's output is complicated when productivity growth does not occur evenly between all industries, which rarely happens. Industries that experience the largest productivity gains should experience a relative decline in the cost of production and, consequently, a relative decline in the prices paid by consumers.

4. The consumption of some goods may actually decline as incomes rise. These goods, typically called "inferior goods" by economists, are special (and uncommon) cases. The origins of the application of income effects as applied to industrial development come from Fisher (1935) and Clark (1957).
Consumers are thus encouraged by lower prices to consume proportionately more goods and services produced by industries that have the largest productivity gains and to consume proportionately less goods produced by industries with low productivity growth. Economists call this the "substitution effect" of a productivity change.

The effect that productivity advancements have on the distribution of national output by industry depends upon the combined influence of the income effect and the substitution effect. If the production of higher-order goods occurs in industries that are experiencing the greatest productivity gains, this industry will unambiguously increase its share of a nation's output. If, however, the most significant productivity gains occur in lowerorder, goods-producing industries, then the income effect and the substitution effect will tend to offset each other.

For example, consider U.S. farming since 1947. Between 1947 and 1985, business productivity increased at an average annual rate of 2.3 percent. That is, on average, the United States economy was able to produce 2.3 percent more per year for the same level of labor expenditure. This represents a significant increase in wealth for the nation. In theory, rising wealth should have encouraged the growth of most U.S. industries (the income effect), but should have encouraged relatively more growth for nonfood goods and services, since they represent a higher-order of consumption than food, which is a basic, low-order consumption item.

However, productivity gains were most prominent in the farming sector, rising at an average annual rate of 4.8 percent over the same 38-year period. Nonfarm productivity rose at a lesser 1.9 percent per year. As a result, the substitution effect probably encouraged the growth of farming relative to nonfarm businesses.

Overall, the income and substitution effects in the farming sector tended to offset each other. Nonetheless, the substitution effect in this case was likely to be weaker than the income effect, since it is commonly believed that the influence of relative prices on food consumption is very small. 5

The evidence from farm output is consistent with the story outlined above. Generally, since 1947, real U.S. farm output has risen, in an absolute sense, by about 1.1 percent per year. But real output by nonfarm businesses rose, on average, at a 3.4 percent annual pace. As a result, the share of farming to total U.S. business output was reduced by more than 50 percent in the postwar period, dropping from about 5.6 percent in 1947 to only 2.4 percent last year.

Income and substitution effects may also explain the changes in the distribution of national output between services, manufactured goods, and nonmanufactured goods since 1950. Again, the economy enjoyed a prolonged increase in national wealth over this period, as output per man-hour increased at an average annual rate of 2.1 percent. This income effect should have encouraged the growth of most indus. tries, but particularly the growth of the service sector. That is, the income effect would probably have tended to decrease the relative growth of manufacturing output and, to an even greater degree, the relative growth of nonmanufactured goods output (such as farming).
5. Goods and services for which the substitition effect is small, that is, where relative price changes have little impact on consumption, are called "price inelastic" goods by economists. The opposite case, goods and services for which the substitution effect is proportionately large, are called "price elastic." 


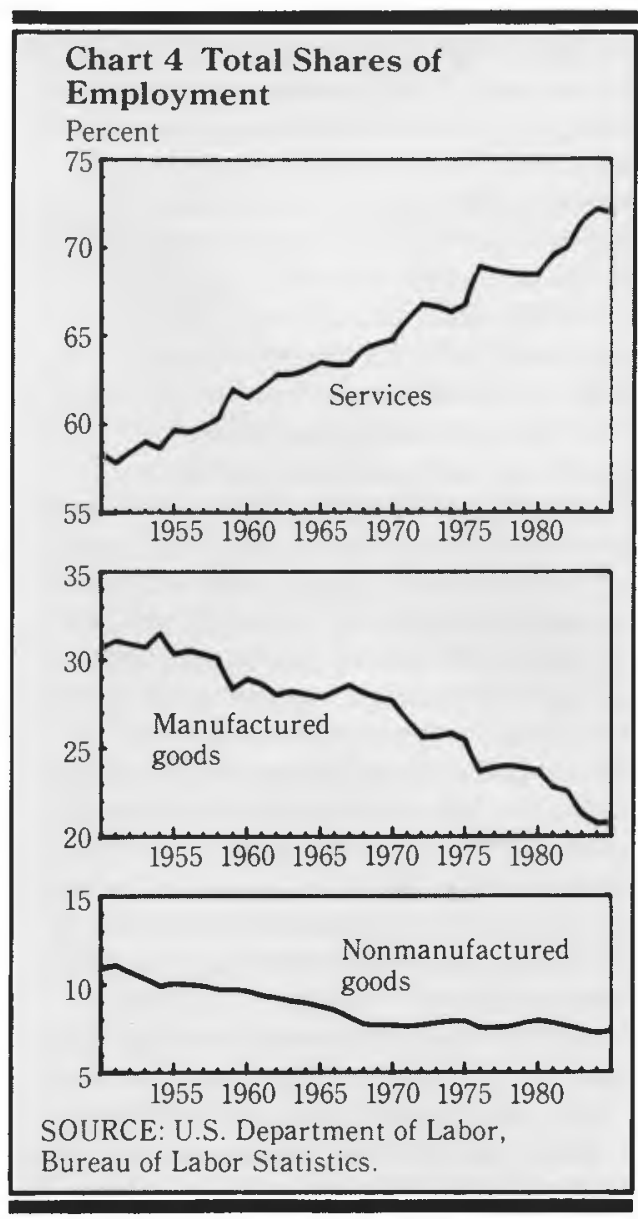

However, the distribution of national output remained relatively constant between 1950 and 1960. Only after 1960 did service-sector production significantly increase its share (chart 3). Further, the post-1960 service sector emergence has come primarily at the expense of the nonmanufactured goods sector, as the share of national output represented by manufacturing remained largely unaffected.

The reason for the behavior of these share shifts, it would seem, has to do with the offsetting substitution effects. Between 1950 and 1960, the nonmanufactured goods industry enjoyed a very large relative increase in productivity, about 5.0 percent per year, on average (chart 5). This was almost twice the average business productivity gain of 2.7 percent. A strong substitution effect in this decade may have allowed the nonmanufacturing sector to completely offset the depressing influence of the income effects over the decade.

Chart 5 Average Annual Growth Rate of Output per Hour

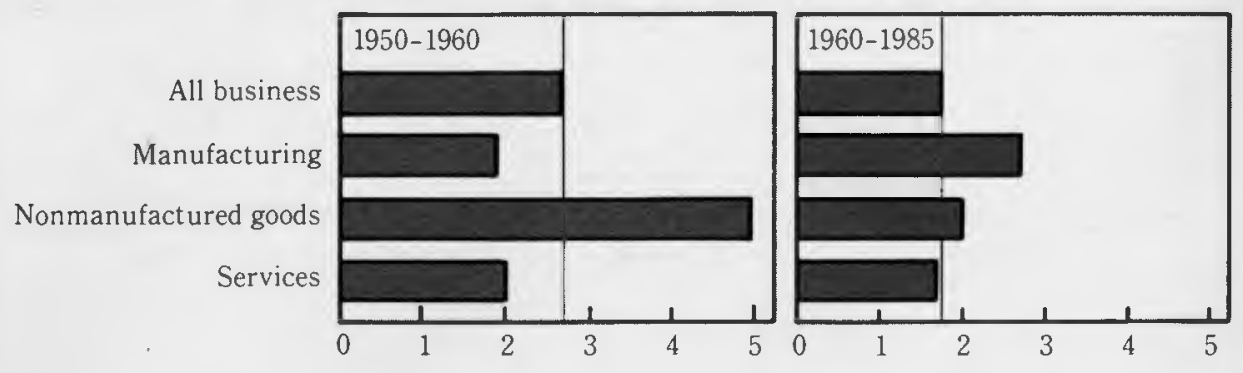

SOURCE: U.S. Department of Commerce, Bureau of Economic Analysis.

After 1960, however, productivity growth for nonmanufactured goods industries began to slow. The offsetting influence of the substitution effect was considerably less during the 1960-1985 period than in the 1950 's. Consequent$1 y$, the relative importance of nonmanufactured goods industries plummeted over the past 25-year period, from 19.6 percent of total real GNP in 1960 to only 10.7 percent in 1984 .

The experience of the manufacturing economy has been somewhat different, probably because the growth in manufacturing productivity, and hence the substitution effects, have helped this sector maintain its share of national output. Between 1960 and 1985, productivity in manufacturing industries rose at an average annual rate of 2.7 percent, compared to only 2.0 percent for nonmanufactured goods industries and only 1.7 percent for service industries.

Where resources are directed, depends upon where the growth in output is occurring relative to the productivity of resources in those industries. For example, because output in manufacturing has tended to maintain a stable share of national output in the postwar period, but productivity in manufacturing has exceeded that of the average U.S. industry, we would expect that manufacturing industries would employ a decreasing share of the work force. This has indeed been the experience of manufacturing workers, who have represented a smaller proportion of total employment virtually through. out the past 35-year period (chart 4).
The nonmanufactured goods industry has also assumed a less important role as an employer, as relatively falling output and about-average productivity growth indicate relatively fewer workers are necessary in these indus. tries. Finally, the service sector has become a more important source of employment, as the relatively high rate of this industry's output growth and relatively low rates of productivity growth require these industries to absorb an increasing share of the national work force.

The issue of the relocation of employment and other productive resources is complicated by demographic changes occurring in the labor force since 1950. Namely, the emergence of women and secondary family workers in the labor market has probably contributed to the relative growth of the service economy in terms of output and employment. If the growth in the labor force has occurred primarily among laborers with a comparative advantage in the production of service output, this would have a depressing influence on service industry wages and prices, and would further encourage the growth of the service economy. ${ }^{6}$

\section{Don't Talk Nonsense}

Critics voicing popular fears claim that the emerging service economy cannot support itself, that relative declines in goods output is a consequence of foreign competition, that the growth in the service economy implies a slowdown in the growth of national wealth, and that redistributions of wealth may eliminate America's middle class.
6. Disproportionately large increases of service workers into the labor market may also account for some of the relatively slow rates of productivity increase in these industries. 
Chart 6 U.S. Trade Balance-Goods and Services (NIA basis)

Billions of 1982 dollars

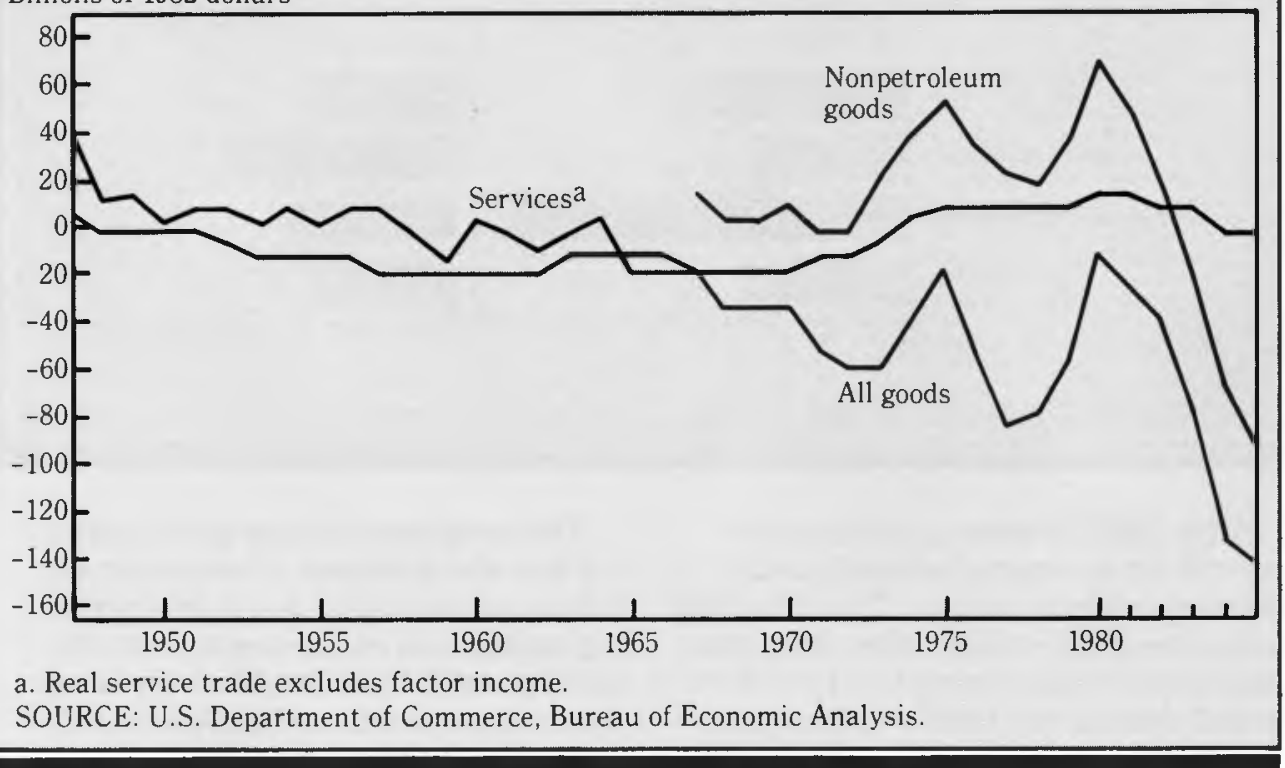

Whether or not the service sector can support itself, however, hardly seems a relevant concern given that output in virtually all goods-producing industries continues to increase. Even the real output of nonmanufactured goods industries is declining only in a relative sense, that is, as a share of total national output. To be sure, the economy is producing more goods today than ever. For example, goods production has risen about 30 percent since 1969. But because of productivity increases in goods industries, this output has been generated using only about 5 percent more labor.

Another common misconception is that the emerging service economy represents an erosion of U.S. goods production by foreign competition. Supposedly, the U.S. is replacing goods output with imports and is exporting proportionately more services. If this were true, however, we would expect that our real trade balance of goods would have declined over time, while the real trade balance of services has increased.

While it is true that real imports of goods from abroad have risen relative to real goods exports throughout most of the postwar period, a closer examination of the trade flows reveals that virtually all of the increase has been related to rising petroleum imports (chart 6). Net U.S. exports of real nonpetroleum goods actually favored U.S. goods producers at an increasing rate between 1967-1980. ${ }^{7}$ Only after 1980 , did dramatic increases in the value of the dollar result in a decline in net nonpetroleum goods export, and a nonpetroleum goods trade deficit since 1983. However, even the rather dra. matic turnaround in real net U.S. nonpetroleum goods exports in recent years has not been associated with a decline in the share of U.S. goods production which remain fairly constant during the 1980s (chart 3). Moreover, real net service exports have been increasing since 1970 , yet the magnitude of real service trade gains have been negligible relative to the general growth of the U.S. service industry.

Overall, while international trade flows may have been important factors in the relative decline of some goods industries during the postwar period, the relative decline of the aggregate goodsproducing sector appears largely unrelated to international trade considerations.

7. Real petroleum trade data are not readily available prior to 1967 . However, given the size of petroleum imports relative to total goods imports prior to 1967 , it is unlikely that earlier data would substantially alter this analysis.
And what about the fears that we will reduce the growth of national wealth? As discussed earlier, the growth rate of productivity in the service economy has been less than that of the goods. producing economy throughout the postwar period. Some believe that shift. ing of resources into an industry with a relatively slow productivity growth is responsible for the nation's lower rate of productivity growth in recent years and, therefore, is responsible for slowing the growth of the economy.

A number of studies, however, have examined the extent to which growing service industry employment has contributed to the slowdown in productivity growth in recent years, reaching es sentially the same conclusions: productivity growth has been uniformly lower in all industries in recent years, the contribution of the intersectorial shifts in production have contributed very little to the overall productivity slowdown and, to the extent that intersectorial shifts have contributed to the slowdown, it has been caused by the shift away from agricul. ture, not from manufacturing. ${ }^{8}$

Ignoring the evidence to the contrary, suppose for the sake of illustration that the emerging service economy were somehow responsible for a slowdown in U.S. productivity growth. Would this in some sense be bad for the economy?

Probably not. In a broad sense, the only way that we can measure the productiv. ity of resources is in terms of how efficient they are in satisfying our desires. Clearly, there are no gains in welfare to be had by producing in industries that have a high growth rate of output per hour if these industries are producing goods that we don't want.

Our economy is devoting more re. sources to the production of services because we now prefer to consume proportionately more education, health care, and information processing, to name but a few growing service industries. Suggesting that we stem the growth of services in the name of national wel. fare is akin to arguing the U.S. should have remained a nation of farmers, because output per worker grew faster in agriculture than in manufacturing.

8. For example, see Denison (1979), Kutscher and Mark (1983), and Fuchs (1978) 
It is often assumed that since some high-paid manufacturing workers are forced to accept lower paying service sector positions, there has been a general lowering of the standard of living for Americans. To be sure, the standard of living for some displaced manufacturing workers is reduced. But the average standard of living in the U.S. must be greater, since it is an increase in aggregate wealth that has primarily brought about the growth of the service economy.

The problems of displaced workers are important ones that public policy may wish to address. But policies aimed at discouraging the service tran. sition by "protecting" goods-producing employment threaten to reduce the standard of living for the entire econ. omy. If we choose to address the potential inequities associated with economic transitions, policies designed to spread the burden of the transition, such as job retraining or other wealth redistribution schemes, should be less costly, and certainly more effective.

Finally, some believe that "the oncesolid middle tier of American jobs has been undermined" by the shift of employment into the service sector which has a smaller portion of middletier jobs. ${ }^{9}$ While the evidence here is not conclusive, Robert Lawrence of the Brookings Institute contends that while the 'middle class' has shrunk from 50 percent of all workers in 1969 to 46 percent in 1983 , very little of this

9. AFL-CIO pamphlet "Deindustrialization and the Two Tier Society." Cited by R. Kirkland, Jr. Are Service Jobs Good Jobs? Fortune (June 10 1985). pg. 38.

Federal Reserve Bank of Cleveland Research Department

P.O. Box 6387

Cleveland, $\mathrm{OH} 44101$ decline can be attributed to the shifting of employment into the service sector. In fact, he found that the greatest reduction in middle-income jobs was in the goods-producing, not serviceproducing sectors. He suggests more likely explanations for the shrinking middle class, namely, an increase in the number of part-time workers, and changes in the age and skill composi. tion of the work force.

\section{Curiouser and Curiouser}

The uncertainties associated with an economy in transition create a great deal of anxiety, such as those which accompanied the Industrial Revolution. In the mid-18th century, for example, just prior to the industrial revolution, a French school of thought called Physiocracy held that all wealth arose from farming. Only the earth, they said, yields more than is put into it, from which surplus the "sterile" efforts of industrialists and others are supported. The problems of the industrial revolu. tion, they believed, were that a growing industrial economy could not support itself, that the movement of resources into the industrial sector would cause starvation, and that the redistribution of wealth from farmers to industrialists was in some sense "unfair."10 Similar sentiments in the U.S. gave rise to a complex series of legislations designed to protect the interests of farmers. Physiocracy, however, had a rather meteoric life, fading in part due to the popularity of the teachings of Adam Smith.

10. The fears such beliefs arouse have, at times, provoked very misguided (but predictable) policy prescriptions. Between 1811 and 1816, one group of English radicals, called Luddites, set out to destroy industrial machinery in the name of jobs creation.
Economic fallacies rarely die, however, they just lay dormant for a time. Echoes of the Physiocrian theory can still be heard in 1986. It would be unfortunate if the transition toward a relatively greater reliance on service production brought with it its own forms of protective legislation, such as industrial policies and protectionist trade laws. A careful examination of the reasons for the relative growth of the service economy make the policies designed to prevent its emergence seem ill-advised-or, as Alice would say, "curiouser and curiouser."

\section{References}

1. Clark, Colin. The Conditions of Economic Progress. New York: St. Martin's Press, 1957.

2. Denison, Edward. Accounting for Slower Eco. nomic Growth: The United States in the 1970s. Brookings Institution, 1979

3. Fisher, Allan. The Clash of Progress and Secur ity. London: Macmillan, 1935.

4. Fuchs, Victor R. The Service Economy. New York: National Bureau of Economic Research and Columbia University Press, 1968.

5. Fuchs, Victor R. "The Service Industries and U.S. Economic Growth Since World War II," in Economic Growth or Stagnation: The Future of the U.S. Economy. Indianapolis: BobbsMerrill Educational Publishing, 1978, pp. 137-156.

6. Kutscher, Ronald E. and Jerome A. Mark. "The Service-Producing Sector: Some Common Perceptions Reviewed," Monthly Labor Review, Vol. 106, No. 4, April 1983, pp. 21-24.
BULK RATE U.S. Postage Paid Cleveland, $\mathrm{OH}$ Permit No. 385
Material may be reprinted provided that the source is credited. Please send copies of reprinted materials to the editor.
Address Correction Requested: Please send corrected mailing label to the Federal Reserve Bank of Cleveland, Research Department, P.O. Box 6387, Cleveland, OH 44101 